Fernando Henrique do Rêgo Monteiro

\title{
A study on the production and characterization of boron doped single wall carbon nanotubes
}

Thesis presented to the Programa de Pós-graduação em Física of the Departamento de Física, PUC-Rio as partial fulfillment of the requirements for the degree of Mestre em Física

Advisor: Prof. Fernando Lázaro Freire Jr. 


\title{
Fernando Henrique do Rêgo Monteiro
}

\section{A study on the production and characterization of boron doped single wall carbon nanotubes}

Thesis presented to the Programa de Pós-graduação em Física of the Departamento de Física do Centro Técnico Científico da PUC-Rio, as partial fulfillment of the requirements for the degree of Mestre.

\author{
Prof. Fernando Lázaro Freire Jr. \\ Advisor \\ Departamento de Física - PUC-Rio
}

Prof. Marcos Assunção Pimenta

UFMG

Prof. Aldo José Gorgatti Zarbin

UFPR

Prof. José Eugenio Leal

Coordinator of the Centro Técnico Científico - PUC-Rio 
All rights reserved.

\section{Fernando Henrique do Rêgo Monteiro}

Received bachelor degree in Physics from Pontifícia Universidade Católica do Rio de Janeiro - PUC-Rio in 2009.

Bibliographic data

Rêgo Monteiro, Fernando Henrique

A study on the production and characterization of boron doped single wall carbon nanotubes / Fernando Henrique do Rêgo Monteiro ; advisor: Fernando Lázaro Freire Jr.. — 2012. $74 \mathrm{f}$. : il. ; $30 \mathrm{~cm}$

Dissertação (Mestrado em Física)-Pontifícia Universidade Católica do Rio de Janeiro, Rio de Janeiro, 2012.

Inclui bibliografia

1. Física - Teses. 2. Nanotubos de carbono; Boro; CVD; Raman; XPS. I. Freire Jr., Fernando Lázaro. II. Pontifícia Universidade Católica do Rio de Janeiro. Departamento de Física. III. Título. 


\section{Acknowledgments}

To God.

To my parents and brother.

To professor Fernando Lázaro Freire Jr, by accepting me for this work, always providing the best research conditions, guidance, discussions, by listening to all my doubts and helping me with them and by the friendship.

To professor Marcelo Eduardo Huguenin Maia da Costa, who helped me a lot in almost everything, including XPS measurements and analysis, Raman measurements, LATEX, many other things that I can not remember now and by the friendship.

To Dunieskys Roberto Gonzáles Larrudé who helped me with discussions, by being the one who had taken the TEM images of this work, for being the one with the greatest contribution on the assembly of the CVD system used on this work and by the friendship.

To my girlfriend Paula Alvarez who always supported and helped me in everything that I need, stayed at my side in every moment, by a little help with LATEX and the grammar corrections of this work.

To Thiago Guerreiro, with whom I had several discussions in almost everything (that is nice) in physics, by the support along this work and by the friendship.

To Erick Costa e Silva Talarico, by the support, discussions, by the great help on the assembly of the first prototype of the CVD system, and by the friendship.

To Fábio Alex Pereira dos Santos, by the several discussions and friendship.

To Carlos Augusto de Oliveira, by all good ideas regarding the CVD system and the friendship.

To Cássia Ribeiro Ponciano, Edson Joaquim, Nilton Cesar Ferreira Gomes, Sérgio Martins Xavier, Gizelda Dias da Silva and all PUC-Rio staff.

To the professors Hiroshi Nunokawa, Welles Antônio Martinez Morgado, Vera Lúcia Vieira Baltar and André Silva Pimentel, by several discussions and friendship.

To all my friends and colleagues who directly or not contributed or supported me on this work.

To PUC-Rio, FAPERJ and CNPq by all the financial support. 


\section{Abstract}

Rêgo Monteiro, Fernando Henrique; Freire Jr., Fernando Lázaro. A study on the production and characterization of boron doped single wall carbon nanotubes. Rio de Janeiro, 2012. 74p. Dissertação de Mestrado - Departamento de Física, Pontifícia Universidade Católica do Rio de Janeiro.

We studied in this work the synthesis and characterization of boron doped single wall carbon nanotubes. They were produced, at different conditions, using a new liquid precursor in a high vacuum chemical vapour deposition system. In order to characterize the samples we compared them to an undoped reference sample and used a transmission and field emission scanning electron microscopy, Raman spectroscopy and a X-ray photoemission spectroscopy (XPS). The transmission electron microscopy and the Raman spectroscopy were used to confirm the presence of single wall carbon nanotubes, while the scanning electron microscopy was used to identify in which temperature range the tubes were produced. We found evidences that the produced sample were doped by comparing the Raman spectra of the samples with the reference one. By using the XPS, we could determine that our tubes are boron doped. By comparing the Raman analysis with the XPS results, we developed a simple rule to estimate the doping level through Raman measurements.

\section{Keywords}

SWNT; Boron; High Vacuum CVD; Raman spectroscopy; XPS. 


\section{Resumo}

Rêgo Monteiro, Fernando Henrique; Freire Jr., Fernando Lázaro. Produção e caracterização de nanotubos de carbono de parede simples dopados com boro. Rio de Janeiro, 2012. 74p. Dissertação de Mestrado - Departamento de Física, Pontifícia Universidade Católica do Rio de Janeiro.

Neste trabalho estudamos a síntese e caracterização de nanotubos de carbono de parede simples dopados com boro, que foram produzidos em diferentes condições, usando um precursor líquido em um sistema CVD de alto vácuo. Para a caracterização comparamos as amostras com outras - de referência sem dopagem - e também usamos microscópios de transmissão e varredura, espectroscopia Raman e espectroscopia por fotoelétrons excitados por raio X (XPS). A microscopia de transmissão e a espectroscopia Raman foram usadas para confirmar a presença de nanotubos de parede simples, enquanto a microscopia de varredura foi usada para identificar em qual faixa de temperatura os nanotubos foram produzidos. Achamos evidências de que as amostras estão dopadas ao compararmos os espectros Raman dos nanotubos com as amostras de referência. Usando os resultados do XPS, determinamos que os nossos tubos estão dopados com boro. Comparando a análise Raman com esses resultados, desenvolvemos uma regra simples para estimar o nível de dopagem a partir de medidas Raman.

\section{Palavras-chave}

Nanotubos de carbono; Boro; CVD; Raman; XPS. 


\section{Contents}

1 Introduction $\quad 12$

2 Carbon nanotubes $\quad 14$

2.1 Carbon 14

$\begin{array}{lll}2.2 & \text { Basic electronic properties of graphene } & 15\end{array}$

$\begin{array}{lll}2.3 & \text { SWNT structure } & 17\end{array}$

$\begin{array}{lll}2.4 & \text { Basic electronic properties of SWNTs } & 19\end{array}$

2.5 Basic mechanical properties of SWNTs and MWNTs 21

2.6 Basic phonon relations of graphene and SWNT 22

3 Production techniques $\quad 24$

3.1 Arc discharge 24

3.2 Laser ablation 25

$\begin{array}{lll}3.3 & \text { Chemical vapour deposition } & 25\end{array}$

$\begin{array}{ll}3.4 & \text { High vacuum CVD } \\ \end{array}$

4 Boron doped carbon nanotubes $\quad 35$

4.1 Synthesis of boron doped carbon nanotubes 35

4.2 Structural and mechanical properties of boron doped carbon nanotubes 37

4.3 Electronic properties of boron doped carbon nanotubes 37

5 Results $\quad 41$

5.1 Experimental set up 41

5.2 Catalyst and precursors $\quad 42$

5.3 SEM images 43

5.4 Raman 45

5.5 X-ray Photoelectron Spectroscopy - XPS 56

5.6 Agreement between XPS and Raman characterization 61

$6 \quad$ Conclusions and future perspectives $\quad 65$

$\begin{array}{lll}6.1 \text { Conclusions and achievements } & 65\end{array}$

6.2 Discussions 65

$\begin{array}{lll}6.3 & \text { Remaining questions or future perspectives } & 66\end{array}$

$\begin{array}{ll}\text { Bibliography } & 68\end{array}$ 


\section{List of Figures}

2.1 A) Shows a graphene sheet being rolled in a SWNT (1) and B) shows a high resolution TEM image of a MWNT (2).

2.2 (a) Shows the graphene's hexagonal structure, unit cell and lattice vectors. (b) Shows the reciprocal lattice vectors (3).

2.3 a) Shows the energy dispersion of the $\pi$ band. b) Shows a zero energy gap on the k point (4)

2.4 The two dashed lines define the limit to the points $(n, m)$ that can form the SWNTs (5).

2.5 This figure shows the reciprocal lattice vectors of a $(4,2)$ SWNT (3). 19

2.6 This figure shows the energy dispersion for a) $(5,5), b)(9,0)$ and c) $(10,0)$ tubes. d) Shows a plot of the density of states for some tubes (3).

2.7 Multi Wall carbon nanotube attached to an AFM tip under a tensile load experiment (6).

2.8 This figure shows phonon dispersion curve of a graphene sheet (7)

2.9 This figure shows a) a mode of the of graphene sheet that gives rise to a nonzero mode on a carbon nanotube and b) an acoustic mode of graphene that can not be applied on SWNTs (3).

2.10 This figure shows a) phonon dispersion curve and b) a plot of the density of states of a $(10,10)$ SWNT taking in account the curvature effects into the dynamical matrix (3).

3.1 Diagram of a arc discharge scheme (5).

3.2 Diagram of a laser ablation scheme (5).

3.3 Scheme of chemical vapour deposition method (5).

3.4 MWNTs prepared using a solution of Toluene and Ferrocene as the carbon precursor and catalyst respectively. Image provided by PUC-Rio

3.5 The figure on the left shows an aligned forests of long tubes and on the right the growth over a controlled area (8).

3.6 Adapter and the o-ring that seals the quartz tube.

3.7 Scheme of the high vacuum CVD system that we used.

4.1 Plot of the calculated energy dispersion relations and the density of states of a a) $0 a t \%, b) 6.25 a t \%, c) 12.5 a t \%$ and d) $25 a t \%$ for a $(16,0)$ boron doped SWNT $(9)$.

4.2 a) Shows the STS data for the doped and undoped sample and b) shows the theoretical local density of states associated with a $\mathrm{BC}_{3}$ nanodomain (10).

5.1 Typical SEM images of tubes produced using Triethyl borate at a) $740^{\circ} \mathrm{C}$, b) $800^{\circ} \mathrm{C}$, c) $840^{\circ} \mathrm{C}$, and d) $900^{\circ} \mathrm{C}$.

5.2 SEM images of a reference sample produced using Ethanol at $850^{\circ} \mathrm{C}$. This temperature gives the highest amount of produced tubes for this precursor. 
5.3 TEM image of a sample prepared using Triethyl borate at $800^{\circ} \mathrm{C}$. It is possible to confirm the presence of SWNTs with diameter around $1 \mathrm{~nm}$.

5.4 Katura plot from Dr. Prof. Shigeo Maruyama's page (http://www.photon.t.u-tokyo.ac.jp/ maruyama/index.html).

5.5 On the left, RBM of samples prepared with Ethanol at different temperatures and the Raman spectra of the reduced catalyst at the same region

5.6 On the right, RBM of samples prepared with Triethyl borate at different temperatures and the Raman spectra of the reduced catalyst at the same region.

5.7 Plot of $D$ and $G$ bands of the Raman spectra of the tubes produced by Triethyl borate. The arrow indicates the position of the $D$ band

$5.8 \mathrm{I}_{D} / \mathrm{I}_{G}$ for both boron containing samples and the reference samples. The error bars are due to different points on the sample.

$5.9 \mathrm{G}^{-}$and $\mathrm{G}^{+}$bands of the samples prepared by Triethyl borate at several temperature.

$5.10 \mathrm{G}^{+}$band of a sample prepared by Triethyl borate, a reference sample and the laser power. As expected (11), it is clear that a higher laser power heats the sample softening the $\mathrm{G}$ band position, that remains constant for a power bellow $\sim 0.13 \mathrm{~mW}$. The dash line is just to guide the eye. The error bars are due to different points on the sample.

5.11 Typical $\mathrm{G}^{+}$band upshift on the sample prepared by Triethyl borate using a laser power around $0.13 \mathrm{~mW}$. An upshift of $\sim 4 \mathrm{~cm}^{-1}$ is observed.

$5.12 \mathrm{G}^{+}$band position for different growing temperatures and precursors. Laser power used was around $0.13 \mathrm{~mW}$. The error bars are due to different points on the sample.

5.13 Typical $G^{\prime}$ band position of a sample prepared by Triethyl borate. It is possible to fit the spectra by the positions provided by the equation of (12). The laser power used was around $0.13 \mathrm{~mW}$.

5.14 Survey XPS spectrum of a sample prepared using Triethyl borate at $800^{\circ} \mathrm{C}$.

$5.15 \mathrm{XPS}$ of carbon $1 \mathrm{~s}$ peak for the samples prepared at a) $800^{\circ} \mathrm{C}$ and b) $860^{\circ} \mathrm{C}$.

5.16 XPS of boron 1 s peak for the samples prepared at a) $800^{\circ} \mathrm{C}$ and $\mathrm{b}$ ) $860^{\circ} \mathrm{C}$.

5.17 Plot of Carbon at $\% /($ Carbon at $\%+\mathrm{Mg}$ at $\%)$ for each growing temperature.

5.18 Doping comparison between XPS measurements and the predicted value obtained using the formula $460 \Delta f \sim \Delta \omega$. The upper graph is the measurements done for the samples prepared using Triethyl borate and the lower graph shows the measurements for the samples synthesized using Triisopropyl borate. 
5.19 This plot shows the fitting using the new parameter $k \sim 420$ obtained from the experimental data. The upper graph is the measurements done for the samples prepared using Triethyl borate and the lower graph shows the measurements for the samples synthesized using Triisopropyl borate. 
"- Data, find a way to defeat that shield.

- That may be impossible, sir.

- Things are only impossible until they're not.

- Yes, sir."

Picard and Data, Star Trek, TNG. 